\title{
絵画にみる鳴門海峡の風景認識の変遷に関する研究
}

\section{A Study on the Historical Change of Landscape Recognition in Naruto Strait Based on Paintings}

\author{
大平 和弘 ${ }^{*}$ 藤本 真里 ${ }^{*}$ 福本 優* 赤澤 宏樹** \\ Kazuhiro OHIRA Mari FUJIMOTO Yu FUKUMOTO Hiroki AKAZAWA
}

\begin{abstract}
Naruto Channel located at the edge of Awaji Island and Shikoku is a scenic beauty known for whirlpools. In this study, we considered the historical change of landscape recognition of Naruto Strait based on the analysis of paintings. We analyzed 56 paintings drawn at the present since the Edo period. As a result of analyzing the composition of paintings and the viewpoint on which paintings were drawn, the paintings were divided into four periods. And, as a result of extracting landscape elements and actual landmarks around the Naruto Strait from paintings, we considered the following the landscape recognition. In the first period, the panoramic landscape that depicts a lot of landscape elements in a wide area was mainstream. In the $2 \mathrm{nd}$ period, the image of the picturesque landscape of whirlpools was established. The 3rd period was the times of exploring new natural landscape images with the theme at the center of the frame. In the 4th period, there were many landscapes that focused on the dynamic whirlpools from the ship.
\end{abstract}

Keywords: painting, landscape recognition, viewpoint, Naruto strait キーワード：絵画, 風景認識, 視点場, 鳴門海峡

\section{1. はじめに}

\section{(1) 背景および目的}

鳴門海峡は, 淡路島南西端（兵庫県南あわじ市）と四国の北東 端（徳島県鳴門市）との間に位置し，太平洋と瀬戸内海をつなぐ 幅約 $1.3 \mathrm{~km}$ の海峡で, 独特の地形と激しい潮流が生み出す渦潮と ともに，多くの絵画や文学等の題材として親しまれてきた。古く は歌川広重の六十余州名所図会 (1853 1856 年), 日本八景 $(1927$ 年) や新日本百景 (1957 年), 平成百景 (2009 年) 等にも繰り返 し選定されてきたわが国有数の景勝地であり, 1931 年に名勝指定 (徳島県側), 1952 年に瀬戸内海国立公園に編入された。近年, 地域振興に向けた世界遺産登録への機運の高まりから，鳴門海峡 の渦潮の世界遺産登録を目指寸「兵庫・徳島「鳴門の渦潮」世界 遺産登録推進協議会」が 2014 年に発足し, 鳴門海峡や渦潮の自 然的・文化的価值の両側面からの学術調査が進められつつある 1)。 この中で，鳴門海陕の類まれな自然美としての価值証明や，登録 区域・構成資産等の検討においては，過去から現在に至る鳴門海 峡の風景の価值認識の変化や，一体的な風景として認識される地 理的範囲に関寸る多面的検討が求められている 1)。本研究では, 絵画として描か冯た鳴門海峡の風景に着目し，描かれた要素や視 点場, 地理的な認識範囲から, 鳴門海陕における風景認識の特徵 とその変遷について明らかとすることを目的とする。

\section{(2) 研究の位置づけ}

これまで，鳴門海峡の風景や景観を扱った研究事例はなく，鳴 門海峡の絵画に関する研究としては，近世絵画に描力れた鳴門海 峡について論じた絵画史的報告書 ${ }^{2}$, 鳴門海峡や渦潮に関する文 学・芸術を収集した文献3) のほかは, 特定の絵師の美術史的研究 に解説がみられる ${ }^{4}$ 程度である。また，絵画に描かれた要素や空 間構成から風景の認識や変遷等を読み説いた研究として, 江戸名 所や富士山・筑波山を対象としたもの $5^{\sim 7)}$ など研究の蓄積がみら れるが，海峡や海岸風景を主として扱ったものは存在せず，研究 事例の蓄積が求められる。

\section{2. 研究方法}

対象とした絵画は, 先行研究・文献 2 4) に記載のある絵画, Cinii （国立情報学研究所）および国指定文化財等データベース（文化 庁）において「鳴門」のキーワード検索で抽出した絵画から, 制 作年代と構成要素の分析に耐え得る精度の画像が得られた 56 件 を選定した (制作年代は江戸中期の 1735 年から現代の 1969 年ま でとなった)。まず, 描写手法を整理するため, 絵画の構図と視点 位置を整理した。構図は, 図一1 のようにパノラマ的に全景を写 実した「全景構困」と主題とする対象物を絞り込んだ「主題構困」 に分類し (主題の対象についても抽出), 視点位置は対象との位置 関係で「俯瞰」と「水平」に分類した。次に，風景を捉えた場所 である絵画の視点場を，描かれた山や岬・島影などの位置関係か ら, 現地調查およびGoogle Earth Proの航空写真と地形表示機 能により特定し, 地図上に図示した。これら構図・視点位置・視 点場の結果より時代的傾向を検討し，56 件を制作年代順に「第 1 期」「第 2 期」「第 3 期」「第 4 期」の 4 つに時期区分した。続い て, 時期区分ごとに捉えられた風景の特徴を読み解くため, 描か れた風景の構成要素を, 「土地構成要素（山，岩，岬・入江，浜， 島)」「海面描写 (渦, 湧昇渦, 白波, う水り, 風浪, 水位差)」「人 工物（帆船，木船，汽船，街道，集落，茶屋，神社・鳥居，その 他)」「人物（漁師，旅人，宴，その他）」「動植物等（黒松，その 他樹木, 草, 鳥, 怪異)」「空 (雲・太陽)」の 30 種に分類抽出し, 時期区分ごとに描写頻度を求めた。また，描か冯た風景の地理的 な認識範囲を把握するため, 範囲を特定する上で目印となり得る 実在する土地構成要素を「ランドマーク」として捉え,「山（諭鶴 羽山, 行者ヶ获, うずの丘, 大毛山, 先山, 大麻山, 芙蓉山, 天 円山)」「岩 (中瀬, 烏帽子岩, 夫婦岩)」「岬・入江 (門崎, 銚子 口, 行者ヶ鼻, 孫崎, 押登岬, 鎽崎, 福良湾, 潮崎, 紀州, 大磯 崎, 島田岬, 椿泊岬)」「浜 (千鳥ヶ浜, 相ヶ浜, 大毛島海岸)」「島

(裸島, 飛島, 大園島, 網干島, 沖ノ島, 弁天島, 沼島, 小豆島, 伊島)」の 35 地点を絵画より抽出した。さらに, 時期区分ごとの

\footnotetext{
*兵庫県立人と自然の博物館 *兵庫県立大学 自然 - 環境科学研究所
} 

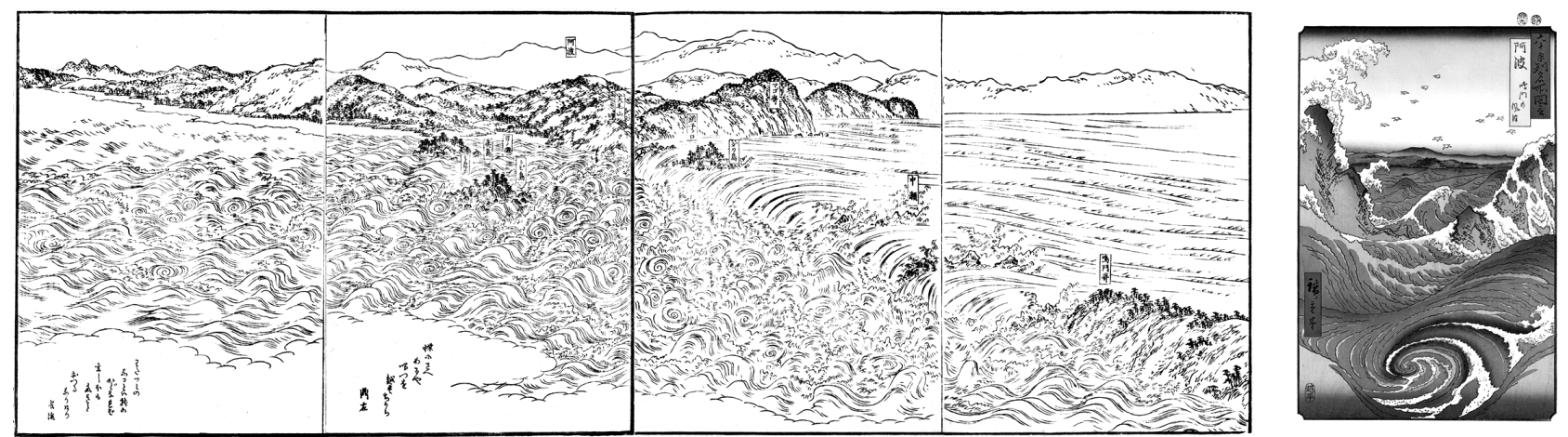

図-1 全景構図（左 : 淡路国名所図会 No. 23 - 部分）と主題構図（右 : 六十余州名所図会 No. 26）の例

表-1 絵画の分析結果と時期区分

\begin{tabular}{|c|c|c|c|c|c|c|c|c|c|c|c|c|c|c|c|c|c|c|c|c|c|c|}
\hline \multirow[b]{3}{*}{$\begin{array}{l}\text { 時 } \\
\text { 期 } \\
\text { 分 }\end{array}$} & \multirow[b]{3}{*}{ No. } & \multirow[b]{3}{*}{ 年代 } & \multirow[b]{3}{*}{ 題 } & \multirow[b]{3}{*}{ 書誌名 } & \multirow[b]{3}{*}{ 絵師·画家 } & \multirow{2}{*}{\multicolumn{3}{|c|}{ 構図 }} & \multirow{2}{*}{\multicolumn{2}{|c|}{ 視点位置 }} & & & & & 視点 & & & & & & & \\
\hline & & & & & & & & & & & & & 德島俱 & & & & 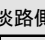 & & & & 構 & 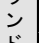 \\
\hline & & & & & & $\begin{array}{l}\text { 㝨 } \\
\text { 構 } \\
\text { 図 }\end{array}$ & $\begin{array}{l}\text { 主 } \\
\text { 題 } \\
\text { 冓 }\end{array}$ & $\begin{array}{l}\text { 主 } \\
\text { 題 } \\
\text { 象 }\end{array}$ & $\begin{array}{l}\text { 俯 } \\
\text { 瞰 }\end{array}$ & $\begin{array}{l}\text { 水 } \\
\text { 平 }\end{array}$ & \begin{tabular}{|l|} 
鳴 \\
門 \\
山
\end{tabular} & $\begin{array}{l}\text { お } \\
\text { 茶 } \\
\text { 園 }\end{array}$ & \begin{tabular}{|l} 
裸 \\
島 \\
正 \\
面
\end{tabular} & 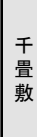 & $\begin{array}{l}\text { そ } \\
\text { の } \\
\text { 他 } \\
\text { 德 } \\
\text { 島 }\end{array}$ & \begin{tabular}{|l} 
門 \\
崎
\end{tabular} & $\begin{array}{l}\text { 行 } \\
\text { 者 } \\
\text { 鸛 }\end{array}$ & $\begin{array}{l}z \\
\text { 雨 } \\
\text { 他 } \\
\text { 淡 } \\
\text { 路 }\end{array}$ & $\begin{array}{l}\text { 海 } \\
\text { 上 }\end{array}$ & $\begin{array}{l}\text { 不 } \\
\text { 明 }\end{array}$ & $\begin{array}{l}\text { 成 } \\
\text { 票 } \\
\text { 数 }\end{array}$ & $\begin{array}{l}\text { ド } \\
\text { ₹ } \\
1 \\
3 \\
\text { 数 }\end{array}$ \\
\hline & 1 & 1735 & 鳴門図 & 絵本和比事 & 西川祐信 & & - & 人物等 & & - & & & & & & & & & & $\bullet$ & 9 & 0 \\
\hline & 2 & 1771 & 鳴門海月之図 & 厳島絵巻艦 & $\mid$\begin{tabular}{|l|l} 
藤原惇則 \\
\end{tabular} & & - & 白波·岩 & & - & & & & & & & & & & - & 5 & 0 \\
\hline & 3 & 1796 & |大毛山望鳴門 & 鳴門十二勝真景図巻 & 鈴木芙蓉 & - & & & - & & - & & & & & & & & & & 13 & 17 \\
\hline & 4 & 1796 & |大磯崎 & 鳴門十二勝真景図巻 & 鈴木芙蓉 & - & & & & - & & & & & - & & & & & & 10 & 11 \\
\hline & 5 & 1796 & 裸島望大毛山 & 鳴門十二勝真景図巻 & 鈴木芙蓉 & - & & & & - & & & & & & & & & - & & 11 & 10 \\
\hline & 6 & 1796 & |裸島望門崎 & 鳴門十二勝真景図巻 & 鈴木芙蓉 & - & & & - & & & & & & - & & & & & & 16 & 10 \\
\hline & 7 & 1796 & 鳴門中流 & 鳴門十二勝真景図巻 & 鈴木芙蓉 & - & & & - & & & & & & & & & - & & & 11 & 7 \\
\hline & 8 & 1796 & 鳴門北面 & 鳴門十二勝真景図巻 & 鈴木芙蓉 & - & & & - & & & & & & & & & & • & & 9 & 9 \\
\hline & 9 & 1796 & 鳴門東岸 & 鳴門十二勝真景図巻 & 鈴木芙蓉 & - & & & - & & & & & & & & & & - & & 12 & 10 \\
\hline & 10 & 1797 & 鳴門暁景図 & & 鈴木芙蓉 & - & & & - & & - & & & & & & & & & & 14 & 13 \\
\hline & 11 & 1800年以降 & 阿波ナル戸 & 中国四国名所旧跡図 & 西丈 & - & & & - & & - & & & & & & & & & & 9 & 8 \\
\hline 第 & 12 & 1800年代 & & & 守住貫魚 & - & & & & - & & & $\bullet$ & & & & & & & & 9 & 13 \\
\hline 1 & 13 & 1800年代 & 阿波国鳴門之図 & & 森魚淵 & - & & & - & & & - & & & & & & & & & 5 & 7 \\
\hline 期 & 14 & 1800年代初頭 & 鳴門 & & |月围 & - & & & - & & - & & & & & & & & & & 7 & 11 \\
\hline & 15 & 1800,1802 & 阿波鳴門·阿波鳴門其二 & 山水奇観 & 淵上旭江 & - & & & - & & - & & & & & & & & & & 16 & 22 \\
\hline & 16 & 1814 & 鳴門真景 & 阿波名所図会 & 探古室墨海 & - & & & - & & • & & & & & & & & & & 19 & 15 \\
\hline & 17 & 1815 & 鳴門図 & 阿波志 & 阿波藩絵師 & - & & & - & & & & & & & & & & - & & 6 & 12 \\
\hline & 18 & 1817 & 阿波の鳴門 & 北斎漫画 & 葛飾北斎 & & - & 白波·岩 & & - & & & & & & & & & & - & 4 & 0 \\
\hline & 19 & 1823 & 鳴門の渦潮 & & シーボルト(著者) & - & & & - & & & & & & - & & & & & & 9 & 8 \\
\hline & 20 & 1833 & 鳴門眺望之景 & 四国遍路道中雑誌 & 松浦武四郎 & - & & & - & & - & & & & & & & & & & 10 & 14 \\
\hline & 21 & 1836 & 阿州鳴門図 其一其二 & 莫逆閑友 & 長谷川雪旦 & - & & & - & & - & & & & & & & & & & 11 & 9 \\
\hline & 22 & 1850 & 鳴門真景図 & & 守住貫魚 & - & & & - & & & - & & & & & & & & & 18 & 17 \\
\hline & 23 & 1851 & 鳴門崎 & 淡路国名所図会 & 暁鐘成 & - & & & - & & & & & & & & - & & & & 12 & 19 \\
\hline & 24 & 1851 & 鳴門の海底に石鼓出現す & 淡路国名所図会 & 暁鐘成 & & - & 人物等 & & - & & & & & & & & & & - & 4 & 0 \\
\hline & 25 & 1851 & 武文の怨霊松浦主従を兴ませた & 淡路国名所図会 & 暁鐘成 & & - & 人物等 & & - & & & & & & & & & & - & 7 & 0 \\
\hline & 26 & 1855 & |阿波 鳴門之風波 & 六十余州名所図会 & 歌川広重 & & - & 渦·白波·岩 & & $\bullet$ & & & & & $\bullet$ & & & & & & 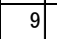 & 3 \\
\hline & 27 & 1857 & 阿波鳴門之風景 & & 歌川広重 & - & & & - & & & & - & & & & & & & & 11 & 18 \\
\hline & 28 & 1859 & 阿波鳴門真景 & 諸国名所百景 & 二代歌川広重 & & - & 渦·裸島 & - & & & - & & & & & & & & & 12 & 5 \\
\hline & 29 & 1862 & |鳴門之真景 & |雲錦随筆 & 松川半山 & - & & & - & & & & & & & & - & & & & 12 & 7 \\
\hline 第 & 30 & 明治期 & |日本名勝阿波鳴門之圖 & & 不詳 & & - & 渦·岩 & & - & & & & & & & & - & & & 11 & 4 \\
\hline 2 & 31 & 1876 & 阿波国鳴門の風波 & 日本地誌略図 & 安藤廣重 (三代) & & - & 渦·白波·岩 & & - & & & & & - & & & & & & 8 & 2 \\
\hline 期 & 32 & 1883 & 皇国阿波鳴門真景之図 & & 加野櫟堂 & - & & & - & & & & & & - & & & & & & 11 & 5 \\
\hline & 33 & 1892 & 阿波国鳴門真景 & & & - & & & - & & - & & & & & & & & & & 17 & 18 \\
\hline & 34 & 明治30年頃 & 阿波鳴門 & 海内勝景 & 富岡鎧斎 & & - & 渦·裸島 & - & & & - & & & & & & & & & 5 & 1 \\
\hline & 35 & 1905 & 阿波鳴門之図 & & 永松春洋 & & - & 裸島 & & - & & & $\bullet$ & & & & & & & & 8 & 4 \\
\hline & 36 & 1915 & 小松島·阿波鳴門図屏風 & & 野口小蘋 & - & & & - & & & & - & & & & & & & & 14 & \\
\hline & 37 & 大正-戦前 & 裸島 & & 中川規矩穈 & & - & 裸島 & - & & & & & $\bullet$ & & & & & & & 3 & 1 \\
\hline & 38 & 1916 & 鳴門 & 秋津百景 & 川端玉章 & & - & & - & & & & & & & • & & & & & 5 & 9 \\
\hline & 39 & 1917 & 阿波の鳴門 & & 中川八郎 & & - & 裸島·帆船 & - & & & & & - & & & & & & & 13 & 8 \\
\hline & 40 & 1925 & 鳴門観潮画巻 & & 湯田玉水 & & - & 渦·その他 & & - & & & & & & & & & & & 5 & 0 \\
\hline & 41 & 1929 & |鳴門 & & 川端龍子 & & - & 渦·その他 & & - & & & & & & & & & & - & 7 & 0 \\
\hline 第 & 42 & 1929 & 渦まく鳴門 & & 山元春汀 & & - & 渦·裸島 & - & & & & & - & & & & & & & 10 & 2 \\
\hline 期 & 43 & 1947 & 鳴門(御茶園よりの展望) & & 三木辰夫 & & - & 裸島 & - & & & - & & & & & & & & & 8 & 3 \\
\hline & 44 & 1950 & 鳴門 & & 池田遥邨 & & - & & - & & & & - & & & & & & & & 10 & 4 \\
\hline & 45 & 1951 & 鳴門 & & 山本柳雪 & & - & 裸島·飛島 & & - & & & - & & & & & & & & 7 & 5 \\
\hline & 46 & 1951 & 鳴門 & & 小絲源太郎 & & - & & & - & & & & & & & & & - & & 6 & 1 \\
\hline & 47 & 1951 & 鳴門朝色 & & 奥村厚－ & & - & 渦·裸島 & - & & & & & $\bullet$ & & & & & & & 12 & 5 \\
\hline & 48 & 1954 & 鳴門 & & 川西英 & & - & 渦·その他 & - & & & & & & & - & & & & & 10 & 8 \\
\hline & 49 & 1957 & 鳴門潮勢 & & 野上魏 & & & & & $\bullet$ & & & & & & & & & $\bullet$ & & & \\
\hline & 50 & 1959 & 鳴門 & & 奥村土牛 & & - & 渦 & & - & & & & & & & & & • & & 2 & \\
\hline & 51 & 1959 & 渦紋 & & 村上凌雪 & & $\bullet$ & 渦 & & $\bullet$ & & & & & & & & & & $\bullet$ & 3 & \\
\hline 第 & 52 & 1964 & 鳴門 & & |河野太郎 & & - & 裸島 & & - & & & & - & & & & & & & 5 & 2 \\
\hline 期 & 53 & 1964 & 鳴門観潮 & & 長谷川富三郎 & & - & 渦 & & - & & & & & & & & & - & & 4 & 1 \\
\hline & 54 & 1965 & 鳴門 & & |伊原宇三郎 & & - & & & - & & & & & & & & & - & & 6 & \\
\hline & 55 & 1968 & 鳴潮 & & 井上速男 & & - & 白波 & & - & & & & & & & & & - & & 4 & 1 \\
\hline & 56 & 1969 & 鳴門 & & 稲木鳴雪 & & - & 滆·白波·岩 & & - & & & & & & & & & & $\bullet$ & 4 & \\
\hline
\end{tabular}


ランドマークの描写頻度を求め, ランドマークの分布から特定し た風景の認識範囲を地図上に図示した。

\section{3. 結果および考察}

\section{(1) 構図と視点場の変遷と時期区分}

表一 1 に 56 件の絵画を制作年代順に示した。これより, 絵画の 構図については，初期は「全景構図」により全景を写実的に描き 込むことが主流であったのに対し，時代が下るにつれ，渦や裸島 等の対象を主題とした「主題構図」への変化がみられた。これに 連動するように，視点位置についても初期は「俯瞰」が多いのに 対し，1950 年代後半以降は主題を「水平」に捉えた描写のみとな った。また，表一 1 および図一2 の特定できた視点場の分布結果 より, 56 件中半数以上の 31 件が徳島側の陸域が視点場となり, 海上は 10 件，淡路側は 6 件と僅かであった。中でも「鳴門山展 望台 (9 件)」からの風景は繰り返し描か子る特徵があった。一方, 時代別に着目寸ると，視点位置の高い「鳴門山展望台」や「その 他徳島」の視点場は初期に多いのに対し，時代が下るにつれ「鳴 門山展望台」より低い「裸島正面」や「千畳敷展望台」, 新たな視 点場として淡路側の突端の「門崎展望台」などに変化し，1950 年代以降のほとんどが「海上」から風景を捉えているという顕著 な時代的変遷がみられた。

以上のような変遷より，風景の全景を俯瞰で捉える傾向が強い 初期の 25 件を「第1期（No.1〜25)」とし，主に渦を主題とした 主題構図の登場と全景構図の終局までの 11 件を「第 2 期 (No.26 〜36)」と区分した。続いて，新たな視点場も交えて渦や裸島な どの主題を捉え，視点位置が俯瞰の終局までの 12 件を「第 3 期 (No.37〜48)」とし，主に渦を主題に海上から水平に風景を捉え た終盤 8 件を「第 4 期（No.49〜 56)」と区分できた。

\section{（2）時期区分別の構成要素の特徵}

風景の構成要素の描写頻度を図 -3 に示した。その結果, 構成 要素を概観すると, 土地構成要素は実際の海峡の環境に即して 「浜」は少なくなった。海面描写では一般的に連想される渦潮の 「渦」と同程度に，「白波」や海峡部の干満差である「水位差」が 表現されていることが特徴的であり，人工物では「帆船」「木船」 が，動植物では「黒松」が圧倒的に多く描かれ，いずれも鳴門海 峡の風景を特徴づける重要な要素といえる。

一方，描写される構成要素は，時期区分ごとに大きく異なるこ とが明らかとなった。第 1 期は表一 1 の構成要素数にみられるよ うに，多くの構成要素を写実的に描き込み，「茶屋」や「集落」， 「旅人」「宴」など鑑賞者の疑似的な画中参入を誘発することを意 図した人為的要素を好んで描いていた。また怨霊などの「怪異」 が描か冯たことも同時期の特徵である。第 2 期では, 「渦」や「う ねり」などの躍動感ある海面描写,「帆船」や「黒松」など渦潮や 鳴門海峡を特徵づける要素が繰り返し描かれていた。続いて第 3 期では, 描かれる構成要素数が減少する反面,「水位差」や海面を

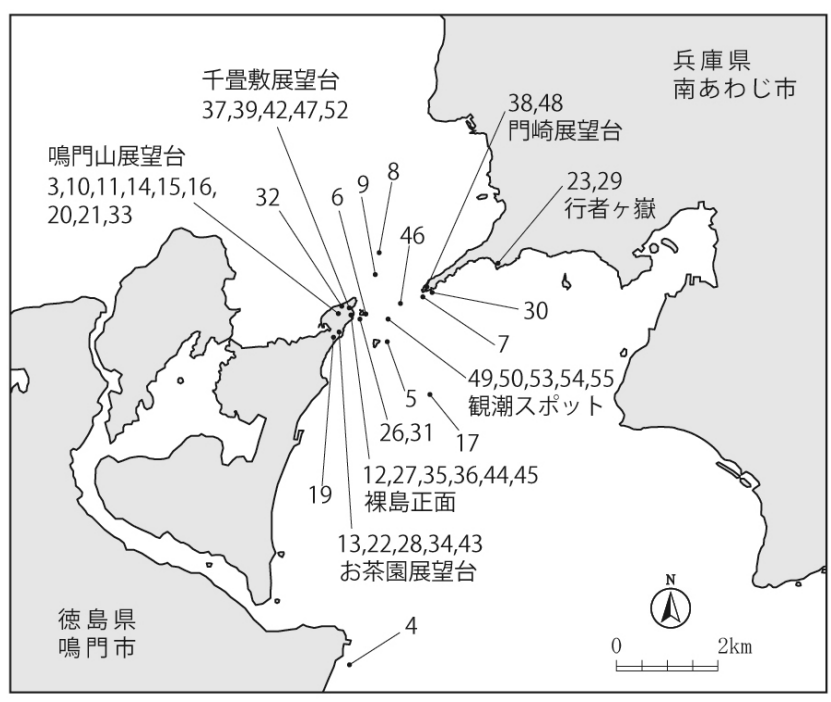

図-2 視点場の分布

よく観察しなければ描けない「湧昇渦」の写実表現に特徴を有す るほか,「木船」やワカメ刈りの「漁師」など, 時代の近代化や機 械化とは逆行した郷愁の風景の要素がみられた。また第 4 期では, 土地構成要素と海面描写以外の構成要素数が激减し,「渦」や「白 波」などの洞潮を描くべき対象として捉えていたと考えられる。

\section{（3）風景の認識範囲とその変遷}

\section{1）ランドマークの描写頻度と認識範囲}

認識範囲を特定する上で重要なランドマークの描写頻度を表一 2 に示した。頻度の高い傾向のあったランドマークに着目寸ると, 海峡淡路端の「門崎（全体での描写頻度 : 71.4\%)」, 海峡央部の 「裸島 (64.3\%)」「飛島 (48.2\%)」と岩礁「中瀬 (46.4\%)」の描 写頻度が高く，これらは海峡を代表するランドマークといえる。 次いで海峡の複雑な地形を表現する「銚子口 $(44.6 \%) 」 に$ 加え, 海峡から離れた「大園島 (32.1\%)」が比較的高い值であることが 特筆される。大園島は一の谷の合戦後の平家が潮待ちした伝承が あり, 歴史認識上重要なランドマークと考えられる。さらに, 山 では淡路島最高峰の「諭鶴羽山 (21.4\%)」が海峡至近の「行者ケ 获 $(21.4 \%) 」 と$ 同程度に描かれ，地理的隔たりにより眺望の難し い「先山 (10.7\%)」も一定程度描かれていた。これは先山が国生 み神話で最初にできた山とする伝承とともに，山頂に淡路霊場と して著名な千光寺を構えることに起因すると考えられる。また, 同様に眺望の難しい「紀州 (12.5\%)」など遼遠の陸影も眺望景の 雄大さを表現する上で重要なランドマークと考えられる。このよ うに, 絵画から得られた鳴門海峡の風景の認識範囲は, 地理的に 認識が容易な海峡周辺部に収まらず, 対象の来歴や絵師の心象も 含めて捉えることの重要性を示唆している。

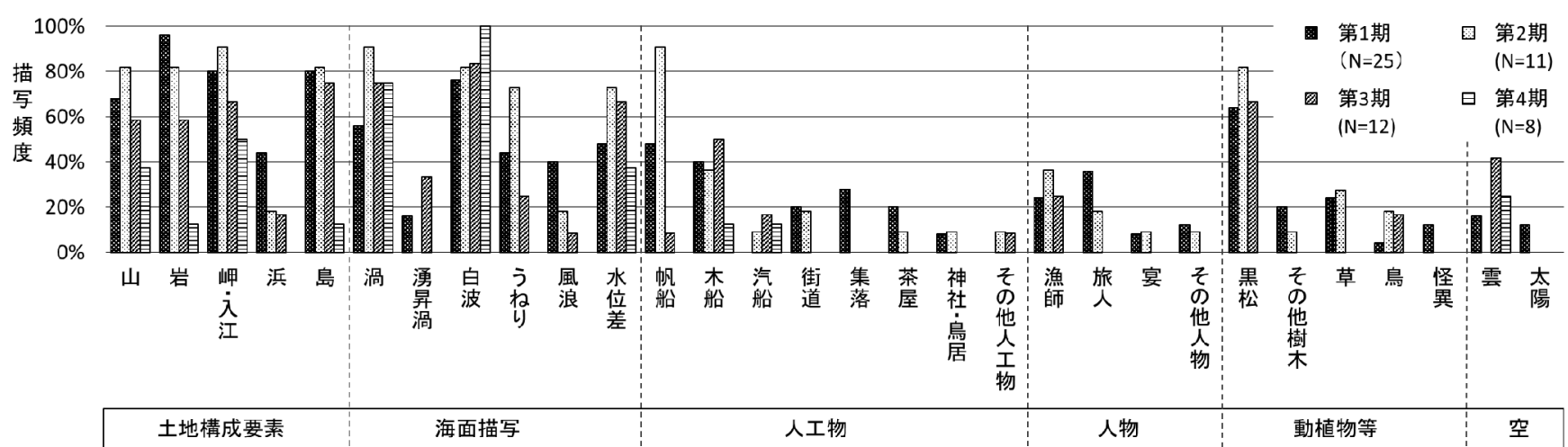

図－3 時期区分別の構成要素の描写頻度 
表－2＼cjkstart時期区分別のランドマークの描写頻度

\begin{tabular}{|c|c|c|c|c|c|c|c|c|}
\hline $\begin{array}{l}\text { 種 } \\
\text { 類 }\end{array}$ & $\begin{array}{l}\text { 記 } \\
\text { 号 }\end{array}$ & 名 称 & $\begin{array}{c}\begin{array}{c}\text { 第1期 } \\
(\mathrm{N}=25)\end{array} \\
\end{array}$ & $\begin{array}{l}\text { 第2期 } \\
(\mathrm{N}=11)\end{array}$ & $\begin{array}{l}\text { 第3期 } \\
(\mathrm{N}=12)\end{array}$ & $\begin{array}{l}\text { 第4期 } \\
(\mathrm{N}=8)\end{array}$ & $\begin{array}{c}\begin{array}{c}\text { 全体 } \\
(\mathrm{N}=56)\end{array} \\
\end{array}$ & 度数 \\
\hline \multirow{8}{*}{ 山 } & $A$ & 諭鶴羽山 & $32.0 \%$ & $18.2 \%$ & $16.7 \%$ & $0 \%$ & $21.4 \%$ & 12 \\
\hline & B & 行者ヶ嶽 & $36.0 \%$ & $27.3 \%$ & $0 \%$ & $0 \%$ & $21.4 \%$ & 12 \\
\hline & C & うずの丘 & $20.0 \%$ & $36.4 \%$ & $0 \%$ & $0 \%$ & $16.1 \%$ & 9 \\
\hline & D & 大毛山 & $16.0 \%$ & $18.2 \%$ & $16.7 \%$ & $0 \%$ & $14.3 \%$ & 8 \\
\hline & $E$ & 先山 & $16.0 \%$ & $18.2 \%$ & $0 \%$ & $0 \%$ & $10.7 \%$ & 6 \\
\hline & $\mathrm{F}$ & 大麻山 & $8.0 \%$ & $9.1 \%$ & $8.3 \%$ & $0 \%$ & $7.1 \%$ & 4 \\
\hline & G & 芙蓉山 & $8.0 \%$ & $0 \%$ & $0 \%$ & $0 \%$ & $3.6 \%$ & 2 \\
\hline & $\mathrm{H}$ & 天円山 & $4.0 \%$ & $0 \%$ & $8.3 \%$ & $0 \%$ & $3.6 \%$ & 2 \\
\hline \multirow{3}{*}{ 岩 } & I & 中瀬 & $72.0 \%$ & $45.5 \%$ & $25.0 \%$ & $0 \%$ & $46.4 \%$ & 26 \\
\hline & J & 烏帽子岩 & $16.0 \%$ & $0 \%$ & $16.7 \%$ & $0 \%$ & $10.7 \%$ & 6 \\
\hline & K & 夫婦岩 & $12.0 \%$ & $0 \%$ & $0 \%$ & $0 \%$ & $5.4 \%$ & 3 \\
\hline \multirow{12}{*}{ 入 } & $\mathrm{L}$ & 門崎 & $76.0 \%$ & $90.9 \%$ & $58.3 \%$ & $50.0 \%$ & $71.4 \%$ & 40 \\
\hline & M & 銚子口 & $56.0 \%$ & $63.6 \%$ & $33.3 \%$ & $0 \%$ & $44.6 \%$ & 25 \\
\hline & $\mathrm{N}$ & 行者ヶ鼻 & $52.0 \%$ & $27.3 \%$ & $8.3 \%$ & $0 \%$ & $30.4 \%$ & 17 \\
\hline & 0 & 孫崎 & $44.0 \%$ & $36.4 \%$ & $16.7 \%$ & $0 \%$ & $30.4 \%$ & 17 \\
\hline & $P$ & 押登岬 & $40.0 \%$ & $18.2 \%$ & $16.7 \%$ & $0 \%$ & $25.0 \%$ & 14 \\
\hline & Q & 鎧崎 & $32.0 \%$ & $9.1 \%$ & $0 \%$ & $0 \%$ & $16.1 \%$ & 9 \\
\hline & $\mathrm{R}$ & 福良湾 & $24.0 \%$ & $18.2 \%$ & $8.3 \%$ & $0 \%$ & $16.1 \%$ & 9 \\
\hline & $S$ & 潮崎 & $24.0 \%$ & $18.2 \%$ & $8.3 \%$ & $0 \%$ & $16.1 \%$ & 9 \\
\hline & T & 紀州 & $20.0 \%$ & $18.2 \%$ & $0 \%$ & $0 \%$ & $12.5 \%$ & 7 \\
\hline & U & 大磯崎 & $16.0 \%$ & $0 \%$ & $0 \%$ & $0 \%$ & $7.1 \%$ & 4 \\
\hline & V & 島田岬 & $4.0 \%$ & $0 \%$ & $0 \%$ & $0 \%$ & $1.8 \%$ & 1 \\
\hline & W & 椿泊岬 & $4.0 \%$ & $0 \%$ & $0 \%$ & $0 \%$ & $1.8 \%$ & 1 \\
\hline \multirow{3}{*}{ 浜 } & $X$ & 千鳥ヶ浜 & $36.0 \%$ & $18.2 \%$ & $8.3 \%$ & $0 \%$ & $21.4 \%$ & 12 \\
\hline & $Y$ & 相ヶ浜 & $8.0 \%$ & $9.1 \%$ & $16.7 \%$ & $0 \%$ & $8.9 \%$ & 5 \\
\hline & Z & 大毛島海岸 & $12.0 \%$ & $0 \%$ & $0 \%$ & $0 \%$ & $5.4 \%$ & 3 \\
\hline \multirow{9}{*}{ 島 } & $a$ & 裸島 & $76.0 \%$ & $72.7 \%$ & $66.7 \%$ & $12.5 \%$ & $64.3 \%$ & 36 \\
\hline & $b$ & 飛島 & $76.0 \%$ & $36.4 \%$ & $33.3 \%$ & $0 \%$ & $48.2 \%$ & 27 \\
\hline & C & 大園島 & $56.0 \%$ & $36.4 \%$ & $0 \%$ & $0 \%$ & $32.1 \%$ & 18 \\
\hline & $d$ & 網干島 & $32.0 \%$ & $18.2 \%$ & $8.3 \%$ & $0 \%$ & $19.6 \%$ & 11 \\
\hline & e & 沖ノ島 & $12.0 \%$ & $9.1 \%$ & $0 \%$ & $0 \%$ & $7.1 \%$ & 4 \\
\hline & $f$ & 弁天島 & $16.0 \%$ & $0 \%$ & $0 \%$ & $0 \%$ & $7.1 \%$ & 4 \\
\hline & g & 沼島 & $8.0 \%$ & $9.1 \%$ & $0 \%$ & $0 \%$ & $5.4 \%$ & 3 \\
\hline & $\mathrm{h}$ & 小豆島 & $8.0 \%$ & $0 \%$ & $0 \%$ & $0 \%$ & $3.6 \%$ & 2 \\
\hline & $\mathrm{i}$ & 伊島 & $0 \%$ & $9.1 \%$ & $0 \%$ & $0 \%$ & $1.8 \%$ & 1 \\
\hline
\end{tabular}

2）時期区分別の認識範囲

表一2 に示す時期区分別のランドマークの描写頻度に着目する と, 総じて第 1 期において頻度が高く, 時代が下るにつれて段階 的に種類と頻度が減少する傾向がみられた。特に第 4 期において 描写されたランドマークは，「門崎」と「裸島」のみであった。こ れらの描写されたランドマークをもとに，時期区分別の風景の認 識範囲を地図上に図示した（図一4）。その結果，海峡中心から南 北約 $80 \mathrm{~km}$, 東西約 $30 \mathrm{~km}$ の四方に拡がりがみられた第 1 期と比 較すると，第 2 期は徳島側の北面・南面の認識範囲が大きく削ら れ, 第 3 期は海峡の視線と平行な東西方向のみの認識範囲となり, 第 4 期は海峡最狭部の 2～3km の範囲のみとなった。

これは，時期区分ごとの視点場の変化に伴い，ランドマークの 視認性が異なっていたことや，主題とする構成要素が変化したこ とが影響したと考えられる。図一-5に代表的な視点場からの絵画 とランドマークの描写状況を示した。「鳴門山展望台」からの「山 水奇観（No.15）」において, 多くのランドマークが視認され描写 されていることに示されるように，第 1 期では標高の高い展望所 からの名所図会など，地理的案内を目的とした絵画の性格が風景 を広域的に認識させたと考えられる。これに対し，第 2 期では図 - 5 の「諸国名所百景 (No.28)」にみられるように, 標高が下が り岬地形により北面の眺望が遮られる「お茶園展望台」などへの 視点場の変化や, 渦潮など海面レベルの主題対象への変化により 認識範囲が狭まっている。また，第 3 期は，淡路側の「門崎」な どの視点場の登場がみられた反面, 徳島側ではより標高が低く渦 や裸島などの主題に近い「千畳敷展望台」や「裸島正面」などへ 視点場が変化し,「鳴門山展望台」からの絵画と比較すると, 遠景 に描かれるランドマークが限られていることがわかる。さらに第 4 期では, 「海上」からの渦潮への主題の特化によって, 認識範囲 が海峡最狭部に集中したものと考えられる。

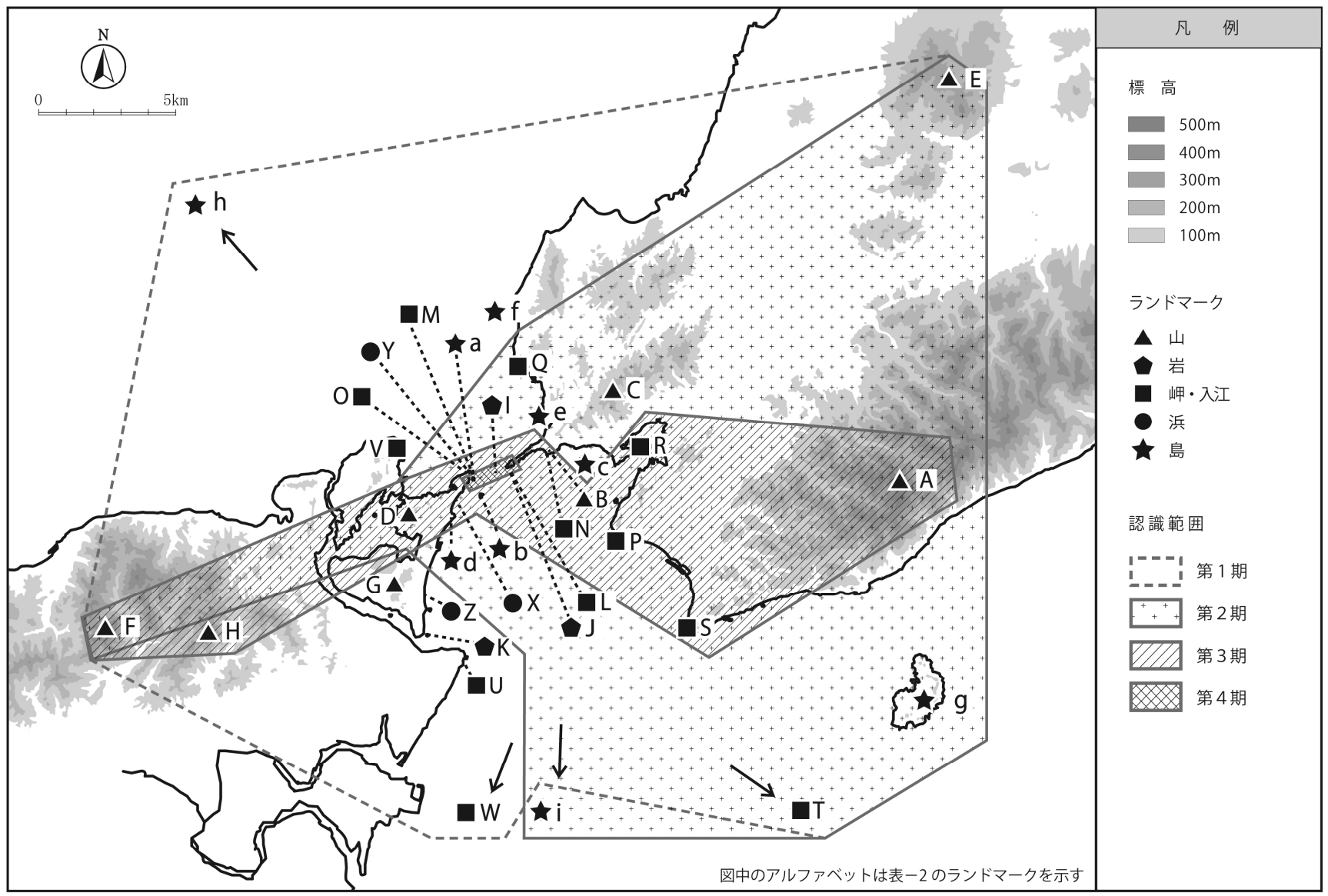

図４＼cjkstart時期区分別の風景の認識範囲 


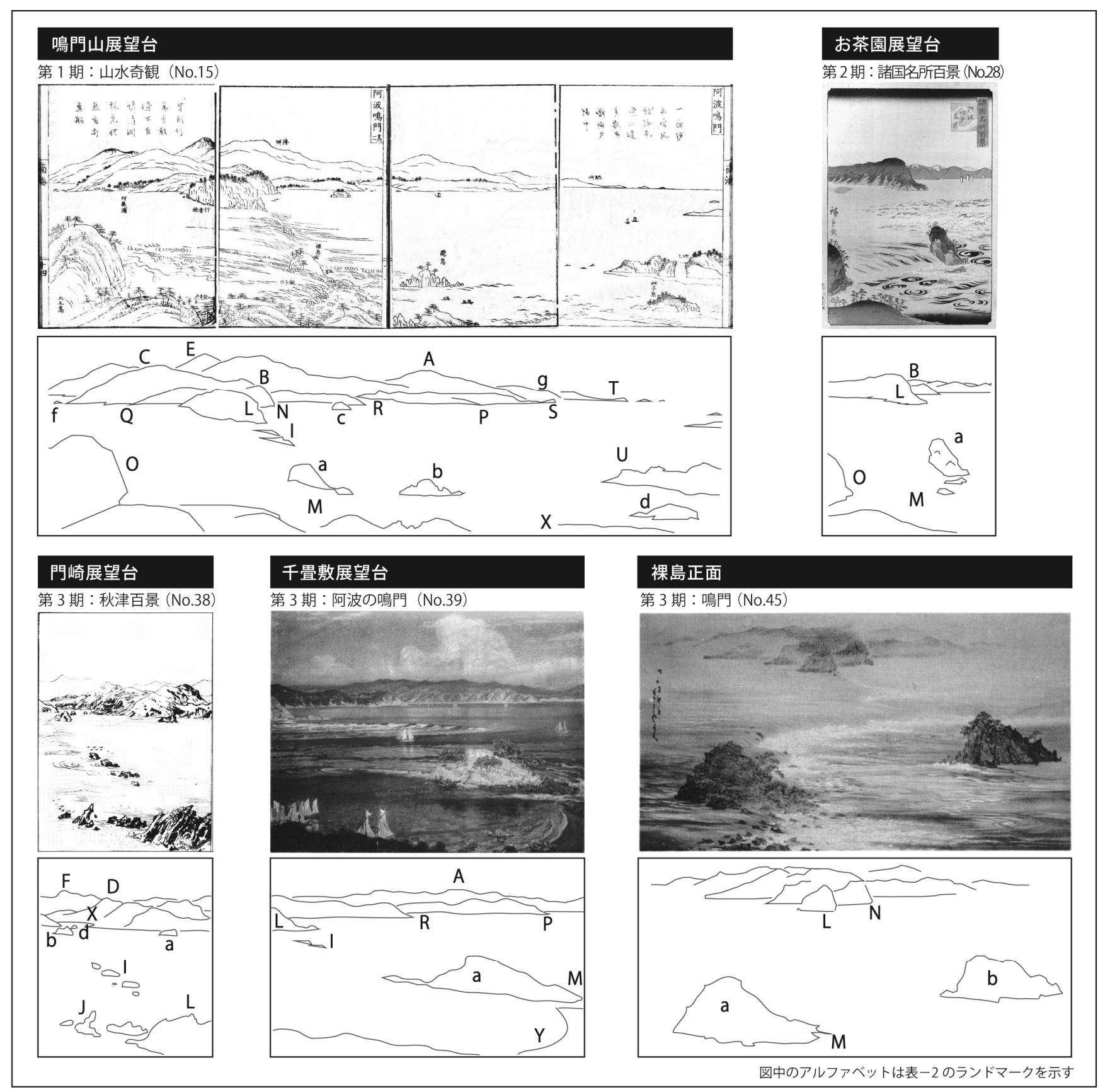

図一5 代表的な視点場からの絵画とランドマークの描写状況

\section{（4）時期区分別の鳴門海峡の風景認識}

第 1 期である江戸中期から後期は, 伝統的な山水画から近代絵 画への過程で, 実景に基づいた科学的な風景画一移行した時期 4,7) であり，特に徳島藩の絵師であった鈴木芙蓉の作品群（No.3-9） 2,4) や, 後世の鳴門海峡の絵画一最も影響力が大きかつたとされる 2) 淵上旭江の「山水奇観 (No.15)」(図一5)により，鳴門山展望 台等からの俯瞰した写実的風景が美的価值の高い見るべき風景と して定型化したといえる。また，図一6 に示す「茶屋と宴を楽し む人々」「旅人」などの描写や，「小豆島の島影」にみられるよう な地理的隔離のあるランドマークの描写より，由緒ある山並みや 島, 遼遠の陸影なども含めた大パノラマの風景を一望する体験に, 鳴門海峡の風景の価值を見出した時代と考えられる。

第 2 期では, それまで鳴門海峡の風景認識に存在しなかった, 海面に自らの視座を仮想し2 渦を主題に海面を水平に捉えた歌川 広重の「六十余州名所図会 (No.26)」(図一1) の発刊が大きな影
響をもたらしたと考えられる。以降，比較的認識範囲の広い雄大 な地形を背景に，うねりや渦など躍動感のある渦潮を主題にしな がら, 帆船や黒松など画趣あふれる要素を好んで取り入れる形で, 二代・三代広重 (No.28,31), あるいは全く別の視点場の淡路側 でも視座を低めに渦や岩肌を主題に捉え，広重の影響を受けたと 思しき版画「日本名所阿波鳴門之圖（No.30）」(図一6) なども発 刊され，「鳴門海峡の渦潮」の象徵的な風景を大衆に広めた時代と 考えられる。

第 3 期における名所図をめぐる背景として, 近世から継続して 描かれてきた対象の減少が示唆される5)ように, 本研究において も第 3 期より第 1 期で好んで描かれた全景構図が消失し, 視点場 の見直しや追加といった同様の変化が確認された。しかし，主題 対象や構成要素の結果より, 近代化に伴う人工的な要素の増加 ${ }^{5}$ ) はみられず，渦や裸島を主題としたものや，むしろ自然を詳しく 観察した渦と湧昇渦の描き分け（図一6）や，木船によるワカメ 


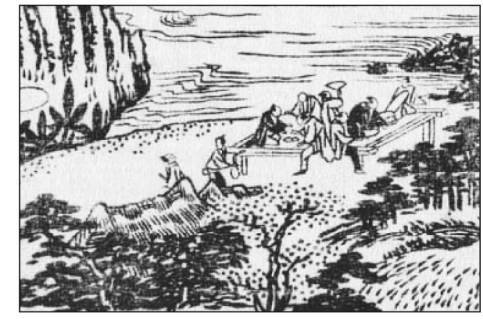

茶屋と宴を楽しむ人々

第 1 期：阿波名所図会 (No.16) - 部分

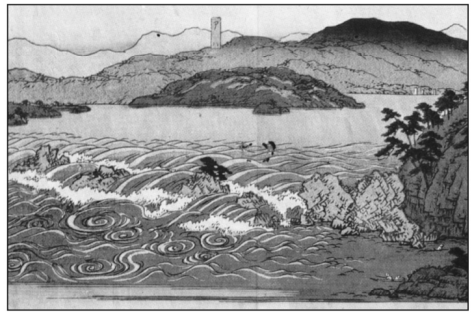

淡路側から渦潮を捉えた版画

第 2 期：日本名所阿波鳴門之圖 (No.30)

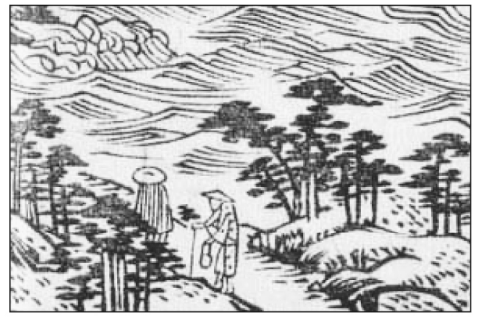

旅人

第 1 期：阿波名所図会 (No.16) ・ 部分

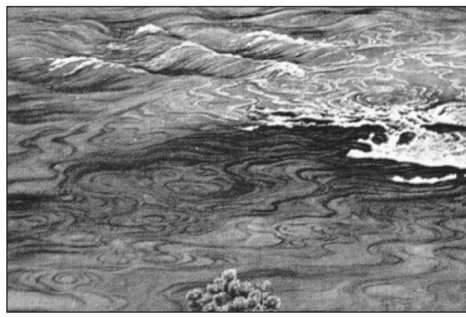

渦（右上）と湧昇渦（左下）の描写

第 3 期 : 渦まく鳴門 (No.42) ・部分

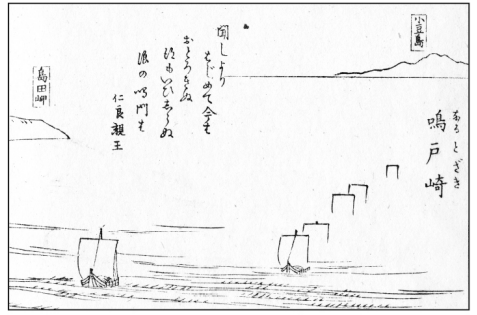

小豆島の島影（右上）

第 1 期: 淡路国名所図会 (No.23) - 部分

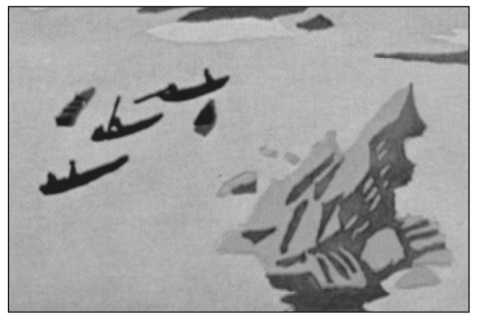

木船によるワカメ刚り

第 3 期：鳴門 (No.48)・部分

\section{図一6 各時期にこ特徵的な表現}

刈り（図一6）などの前時代的要素に特徵を有した。これは，西 洋の風景観による自然科学的見方の獲得による影響 7)に加え, 観 光客誘致を目的とした鳴門公園の改修 (1906 年) や観光船の増便 （1922 年），裸島への栈橋の架橋（1913 年）8）など，主題とする 渦や裸島をより近く認識できるようになった反面，日本八景選定 (1927 年) や名勝指定 (1931 年), 瀬戸内海国立公園編入 (1952 年）に至る景勝地や自然風景地としての価值をめぐる動きなどの 影響を受け 9), 鳴門海峡の新たな自然的風景を模索する風景認識 があったものと推察される。

第 4 期では, 近代日本画の巨匠奥村土牛の傑作「鳴門 (No.50)」 10) に代表されるように, 多くの作品が海上から渦を主題に表現し た作品となっている。この時代は，高度経済成長を背景に観光旅 行が活発化 $\left.{ }^{8}\right)$ し, 当時の観光ガイドには「鳴門海峡でクルーズを 始める予定（1947 年)」や「遊覧船が毎日出発している（1959 年)」などの記載がみられる 11) ことから，観潮船による洞潮観光 が主流化していたことが風景認識に影響したと考えられる。また, 鳴門海峡を横断する送電線の完成 (1961 年), 鳴門公園にドライ ブウェイ完成（1961 年）12）などの海峡周辺部の開発に伴い，陸 域の風景が損なわれていったことも影響した可能性がある。いず れにせよ，この時代には観潮船から間近に捉えた，渦そのものの ダイナミックな風景が，鳴門海峡を象徵する風景として認識され ていたといえる。

\section{4. おわりに}

本研究では，鳴門海峡を描いた絵画を対象に，その構図や視点 場, 描かれた構成要素や地理的な認識範囲の変遷を明らかとした。 その結果，江戸中期から現代に至るまで大きく 4 つの時期区分が みられ，時代とともに描かれる構成要素が変化し，認識範囲が狭 くなる傾向がみられるなど，時代ごとの風景認識の特徵が明らか となった。現在，海陕中央には大鳴門橋が架橋されており，鳴門 海峡の風景に大きな変化をもたらしていると考えられる。本研究 で得られた風景の特徵や風景認識が，どのように継承されている のかについて明らかにすることが今後の課題といえる。
謝辞: 本研究の着想に際しては，兵庫県立人と自然の博物館の中瀬勲館長 をはじめとした兵庫県の鳴門海陕の渦潮世界遺産登録学術調査委員会，兵 庫県淡路県民局，株式会社へッズの皆様，資料や情報提供に際し，徳島県 の「鳴門の洞潮」世界遺産登録学術調查検討委員会, 鳴門市教育委員会, 徳島市立徳島城博物館, 飯田市美術博物館, 山種美術館の担当者の方々に ご協力いただきました。記して謝意を表します。

\section{引用文献}

1）鳴門海狭の渦潮世界遺産学術調查検討委員会 (2017) : 鳴門海狭の渦潮 の学術的価值及び今後の学術調查の方向性に関する報告書:兵庫県, $80 \mathrm{pp}$

2）大久保純一 (2017) : 江戸時代絵画に描かれた鳴門海峡 :「鳴門の䍏潮」 世界遺産登録学術調查報告書～文化編～，27-38

3）鳴門市史編篹委員会（1971）: 鳴門市史別巻 : 鳴門市，1330pp

4）槇村洋介（2018）：鈴木芙蓉の新出作品を巡って（二）：飯田市美術博物 館 研究紀要 $28,7-22$

5）大宮直記・下村彰男・熊谷洋一（1995）: 名所図会・百景にみる近代以 降の東京における「景」の変遷に関する研究:ランドスケープ研究 58(4), 429-437

6）西邑雅末・黒田乃生（2016）：近世絵画にみる筑波山の特徴 : ランドス ケープ研究 79(5), 565-568

7）大竹芙実・山本清龍・下村彰男（2017）: 絵画にみる三保松原と富士山 との関係の変遷と現代の風景認識に関する研究 : ランドスケープ研究 $80(5), \quad 569-574$

8）佐藤正志 (2017)：「観光地・鳴門」の形成・発展とメディア：「鳴門の 洞潮」世界遺産登録学術調查報告書～文化編～， 220-241

9）西田正憲 (1998) : 瀬戸内海における定数名所・観光地等の変遷 : ラン ドスケープ研究 61 (5)，395-400

10）山種美術館学芸部（2010）：山種美術館所蔵 奥村土牛 作品集 : 山種美 術館, $151 \mathrm{pp}$

11）モートン常慈 (2017)：西洋人の目からみた「鳴門の渦潮」「鳴門の渦 潮」世界遺産登録学術調査報告書～文化編～，316-343

12）鳴門市史編纂委員会（1999）：鳴門市史現代編 1 ：鳴門市，1146pp 